Aytaş, G. ve Özcan, Ş. (2019). Türkçe eğitimi konularını temel alan drama çalışmalarına yönelik bir inceleme. Ana Dili Eğitimi Dergisi, 7(1), 235-255.

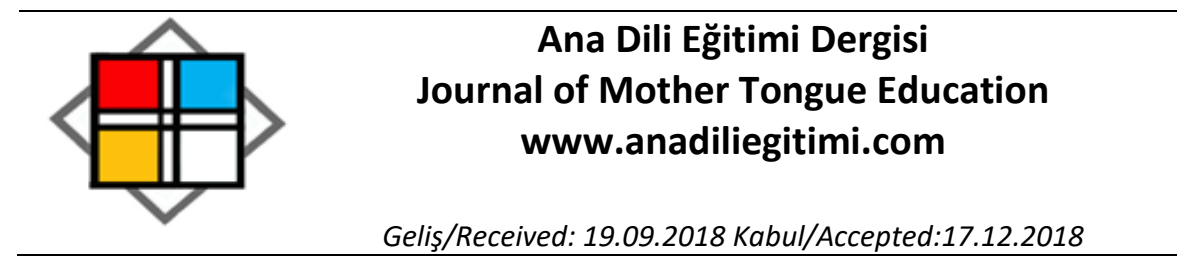

\title{
Türkçe Eğitimi Konularını Temel Alan Drama Çalışmalarına Yönelik Bir İnceleme
}

\author{
Glyasettin AYTAŞ* \\ Şeyda ÖZCAN**
}

\begin{abstract}
Öz
Bu araştırmada, Türkçe eğitiminde drama yönteminin kullanımını temel alan lisansüstü tezler incelenmektedir. Araştırmanın evrenini, 386 tez oluşturmaktadır. Türkçe eğitimi kapsamında yer alan bilim dalı ve ana bilim dalı başlıklarında taranan drama tezleri doğrudan araştırmaya dâhil edilmiştir. Eğitim ve Öğretim konu başlığında, Türkçe eğitimi bilim dalı ve ana bilim dalları içerisinde yer almayan ancak Türkçe eğitimi konuları ile temellendirilen diğer tezlerin de araştırmaya dâhil edilmesiyle 26 yüksek lisans ve 4 doktora tezi olmak üzere 30 tez, araştırmanın örneklemini oluşturmuştur. Araştırma sonucunda, Türkçe eğitimi konularını temel alan drama tezlerinin çoğunlukla uygulama temelli olduğu, yönteme yönelik ilk tezlerin betimsel çalışmalar olarak planlandığı, incelenen tezlerde drama yönteminin kullanımını planlayan model önerilerinin yer aldığı, yöntemin öğrenci başarısı üzerindeki etkisinin araştırıldığı, drama alanında Türkçe öğretmenleri ve öğretmen adaylarının yeterliliklerinin irdelendiği, Türkçe dersi kapsamında, sınırlandırılmış konulara yönelik araştırmaların da yapıldığı görülmüştür.
\end{abstract}

Anahtar Kelimeler: Türkçe eğitimi, drama, lisansüstü tezler

\section{An Investigation on Drama Studies Focusing on Turkish Education Subjects}

\begin{abstract}
The current research aimed to investigate graduate theses based on the creative drama method used in Turkish language arts education. A total of 386 graduate theses were screened for this research. However, research sample only included the theses categorized under the titles related to Turkish Education and the theses which are related to Turkish Education but not under category of Turkish Education. At total 30 theses -26 master's theses and 4 doctoral thesesconstituted the sample of this study. is the research findings revealed that the drama theses on Turkish language education are mostly practice-based, the first but primary theses were conducted as descriptive study. Some of theses analyze the effect of drama on students' academic achievement and some of theses examine Turkish teachers and preservice Turkish teachers' competence level of drama, and there are some studies regarding the use of drama for teaching specific content area of Turkish language course. Also, there are put forward some models and suggestions about how to make use of drama method for teaching Turkish language.
\end{abstract}

Key Words: Turkish language education, drama, theses and dissertations

\footnotetext{
* Prof. Dr., Gazi Üniversitesi, Gazi Eğitim Fakültesi, Türkçe ve Sosyal Bilimler Eğitimi Bölümü, Türkçe Eğitimi Ana Bilim Dalı, Ankara, giyaytas@gazi.edu.tr, ORCID: 0000-0002-1381-1094

** Arş. Gör., Sinop Üniversitesi, Eğitim Fakültesi, Türkçe ve Sosyal Bilimler Eğitimi Bölümü, Türkçe Eğitimi Ana Bilim Dalı, Sinop, seyda-ozcan@hotmail.com, ORCID: 0000-0003-2535-5740
} 


\section{Giriş}

Türkçe eğitiminin sınırlılılarını belirleme, bu sınırlılıklar çerçevesinde ortaya çıkan problemleri çözümleme konusu her zaman sorunlu bir alan olmaktadır. Öncelikle Türkçe eğitimi denilince genel olarak ileri sürülen anlama ve anlatma becerilerinin geliştirilmesi, bir başka söyleyişle dinleme, okuma, konuşma ve yazma becerilerinin geliştirilmesi anlaşılmaktadır. Bu genel değerlendirme kabul edilmiş, âdeta kalıp bir teoriye dönüşmüştür. İşin doğrusu, Türkçe öncelikle bir dil kimliğini belirlemenin ötesinde, kimlik ve mensubiyet unsurlarını da içinde barındıran geniş bir alandır. Türkçenin konuşulduğu ve yazıldığı her alan Türkçe eğitimini ilgilendirmektedir. Bu yüzden dar bir alanda ve kapsamda Türkçe eğitimini değerlendirmek doğru bir anlayış değildir.

Dil, insanın varlık sebebidir. Dilin belli kalıplar ve ilkeler içerisinde tanımını yapmak bir yana, dilin bir olgu olarak insana ait temel bir ihtiyaç göstergesi olduğu bilinmektedir. İlk çağlardan bu yana dilin varlık sebebinin ötesinde, kullanım gereklilikleri her zaman tartışılmış, dil korumacılığının yanında, dilin etkili ve verimli olarak bireyin hayatında yer edinmesi üzerinde de çalışmalar yapılmıştır. Türkçenin eğitiminde, kendi disiplin sınırlılıkları içerisinde yapılması gerekenler, problemlerin tespiti ve çözümü çerçevesinde yapılmış, çoğu zaman bunlar yetersiz kalmıştır. Yetersizliklerin nedenleri ise yeni araştırmalarla ortaya konulmaya çalışıımış ve bu da alanın problemlerinin çözümünü kısır bir döngüye sokmuştur.

Bütün disiplinlerde göz önünde bulundurulan temel unsur, ele alınan konunun hangi yöntem ve teknikle aktarılacağıdır. Bu yöntem ve tekniklerin, etkili ve verimli bir şekilde kullanımının yanı sıra, sonuçlarının da aynı şekilde olması beklenmektedir. Türkçe eğitiminde kullanılan yöntem ve teknikler içerisinde, yaparak yaşayarak öğrenme sürecinin çok etkili olduğu gözlenmiştir. Bu sürecin taşıyıcıları içerisinde dramanın birçok disiplin alanında olduğu gibi, Türkçe eğitiminin de önemli araçlarından biri hâline geldiği görülmüştür.

Drama, yaratıcı drama, eğitici drama gibi farklı adlandırmalar içeren yöntem, içerisinde öğrencilerin deneyim kazanarak ve hissederek öğrenmelerine yardımcı olan, öğrencilerin başkalarının hislerini ve düşüncelerini anlamalarını sağlayan, (Aytaş, 2003) onların yaşadıkları ya da yaşayabilecekleri olayları/durumları hayal etmeleri ya da üretmelerini sağlayan deneyimler içermektedir. Dramanın sağladığı bu yapı, Türkçe eğitiminin amaçlarına ulaşmasında yardımcı olmaktadır.

Günümüzde, çeşitli bilim alanlarında yapılan akademik çalışmalara yönelik değerlendirme ve tespit çalışmaları olduğu gibi, Türkçe eğitimi üzerinde yapılan bilimsel çalışmalarla ilgili akademik yayınların yapıldığı görülmektedir. Özellikle yüksek lisans ve doktora tezleri kimi zaman ilgili 
araştırmalar başlığı altında, kimi zaman da bağımsız olarak ele alınmıştır. Aynı çalışmaların farklı disiplin alanlarında da yapıldığı görülmektedir.

Dramanın genel algısının ötesinde, bir eğitim anlayışının temel başvuru alanı olarak değerlendirilmesi, bir başka söyleyişle dramanın bir yöntem olarak kullanılmasının başarı ölçütlerindeki yeri tartışılmaktadır. Bu tartışmaların yapıldığı akademik çalışmaların bir bütün olarak değerlendirilmesi gerekmektedir. Özellikle Türkçe eğitimi alanında yapılan drama konulu lisansüstü çalışmaların gözden geçirilerek, ele aldıkları temel probleme nasıl yaklaştıkları, bunu nasıl bir çözüme kavuşturdukları ve getirdikleri önerilerin problemi çözmede etkililiği, ortaya konulmalıdır. Elde edilen verilerin hem yeni yapılacak alan araştırmalarında hem de bu alana ilgi duyan araştırmacı ve uygulayıcılara büyük kolaylık sağlayacağı düşünülmektedir. Bu düşünceden hareketle araştırmada, YÖK Ulusal Tez Merkezi Veri Tabanında, Eğitim ve Öğretim konu başlı̆ı içerisinde yer alan ve Türkçe eğitimi konularını içeren drama tezlerini sınıflandırarak değerlendirmek amaçlanmıştır. Belirlenen amaç doğrultusunda çalışma, "Türkçe eğitimi konularını temel alan drama çalışmaları nasıl sınıflandırılabilir?" ana problemi çerçevesinde ele alınmıştır. Türkçe eğitimi konularına yönelik yapılan lisansüstü çalışmaların değerlendirilmesi ile drama tezlerinin ele aldıkları konular, yöntem ve uygulama açısından toplu bir şekilde görülmesi; öğretim programı sürecine dâhil edilebilecek drama uygulamalarından haberdar olunması; Türkçe eğitimi konularına yönelik drama yöntemi çalışma alanlarındaki boşlukların fark edilmesi amaçlanmaktadır.

\section{Yöntem}

\section{Araştırmanın Modeli}

Türkçe eğitimi konularını temel alan, drama yöntemiyle temellendirilmiş yüksek lisans ve doktora tezlerinin incelendiği bu araştırma betimsel niteliktedir ve araştırmada tarama modeli kullanılmıştır. Geçmişte ya da hâlen var olan bir durumu var olduğu şekliyle betimlemeyi amaçlayan araştırmalarda tarama modelleri kullanılmaktadır (Karasar, 2012, s. 77).

\section{Evren ve Örneklem}

Araştırmada, Türkçe eğitimi konularını temel alan ve lisansüstü düzeyde yapılmış drama çalışmaları ele alınmıştır. Araştırmanın evrenini, YÖK Ulusal Tez Merkezi Veri Tabanı içerisinde yer alan, Eğitim ve Öğretim konu başlığı içerisinde taranan, tez adında drama sözcüğü bulunan 386 tez oluşturmaktadır. Araştırmanın örneklemini ise Ulusal Tez Merkezi Veri Tabanı içerisinde Eğitim ve Öğretim konu başlığı altında, Türkçe eğitimi konularını temel alan 30 tez oluşturmaktadır. 


\section{Verilerin Toplanması ve Analizi}

Araştırmada, YÖK Ulusal Tez Merkezi Veri Tabanı tarama bölümünde Konu seçeneği Eğitim ve Öğretim seçilerek, Tez adı seçeneğine drama sözcüğü yazılarak tarama yapılmış ve 386 tez bulunmuştur.

Araştırma kapsamı içerisinde yer alacak çalışmaların belirlenmesinde ise YÖK Ulusal Tez Merkezi Veri Tabanı içerisinde Türkçe Eğitimi Bilim Dalı, Türkçe Öğretmenliği Bilim Dalı, Türkçe Ana Bilim Dalı, Türkçe Eğitimi Ana Bilim Dalı, Türkçe Öğretmenliği Ana Bilim Dalı, Türkçenin Eğitimi ve Öğretimi Ana Bilim Dalı, Türkçe ve Sosyal Bilimler Eğitimi Ana Bilim Dalı altında taranan ve tez başlığı içerisinde drama sözcüğü bulunan 15 tez seçilmiştir. Ardından Eğitim ve Öğretim konu başlığında taranan 386 tez, başlıklarında ve içeriğinde Türkçe eğitimi konusu bulunup bulunmamasına göre irdelenmiştir. Bunun sonucunda Eğitim Bilimleri Ana Bilim Dalı ( $f=7)$, İlköğretim Ana Bilim Dalı $(f=2)$, Ortaöğretim Sosyal Alanlar Öğretmenliği Ana Bilim Dalı $(f=1)$, Sınıf Öğretmenliği Ana Bilim Dalı $(f=1)$ ve Temel Eğitim Ana Bilim Dalı $(f=1)$ içerisinde yer alan 12 tez ile veri tabanında ana bilim dalı veya bilim dalı belirtilmemesine rağmen Türkçe eğitimini temel alan 3 tez, araştırmaya dâhil edilmiştir. Okul öncesi dönemi kapsayıp Türkçe dersi temel dil becerilerini ele alan tezler ise kapsam dışında bırakılmıştır. YÖK Ulusal Tez Merkezi Veri Tabanı aracılığıyla edilen tezlerden, farklı konu başlıkları içerisinde yer alan ya da tez başlığında drama sözcüğü bulunmamasına rağmen Türkçe eğitimi alanında yapılmış drama tezlerinin bulunmasının da olası olduğu belirtilmelidir.

Çalışma verileri toplanırken Ulusal Tez Merkezi aracılığıyla elde edilen 386 tez; tez adı, yılı, tez türü, erişim şekli, ana bilim dalı, üniversite, enstitü kodlamaları ile bir tabloya aktarılmıştır. Araştırma evrenini oluşturan 386 tez ile ilgili tez türü, tezlerin yıllara ve üniversitelere göre dağılımı, tezlerin ana bilim dallarına ve enstitülerine göre dağılımı, tezlerin erişim durumları, yüzde ve sıklık ile ifade edilmiştir. Veriler, grafikler aracılığıyla gösterilmiştir.

Çalışma çerçevesine giren konular ve ana bilim dalları içerisinde yer alan tezler işaretlenerek ayrıntılı okuma yapmak üzere veri tabanından indirilerek kaydedilmiştir. Bu süreçte çalışma örneklemine dâhil edilen ancak kısıtlı olan $(f=1)$ ya da tam metnine ulaşılamayan tezler $(f=4)$ ile karşılaşılmıştır. Veri tabanında yayınlanma izni bulunmayan 4 tez, üniversite kütüphanesi aracılığıyla Ulusal Tez Merkezinden istenmiştir. Kısıtlı olan 1 tez ise özet bölümünden yola çıkarak sınıflandırılmıştır. Ele alınacak tüm tezler ayrıntılı olarak okunduktan sonra sınıflandırılmış ve tablolar aracılığıyla gösterilmiştir. 


\section{Bulgular}

YÖK Ulusal Tez Merkezi veri tabanında Eğitim ve Öğretim konu başlı̆̆ı içerisinde yer alan ve başlığında drama sözcüğü bulunan tezlerin; tür, yıl, üniversite, ana bilim dalı, enstitü ve erişim durumuna göre dağılımları şu şekildedir:

Grafik 1. Eğitim ve öğretim konu başlığı içerisinde taranan drama tezlerinin tez türüne göre dağılımı

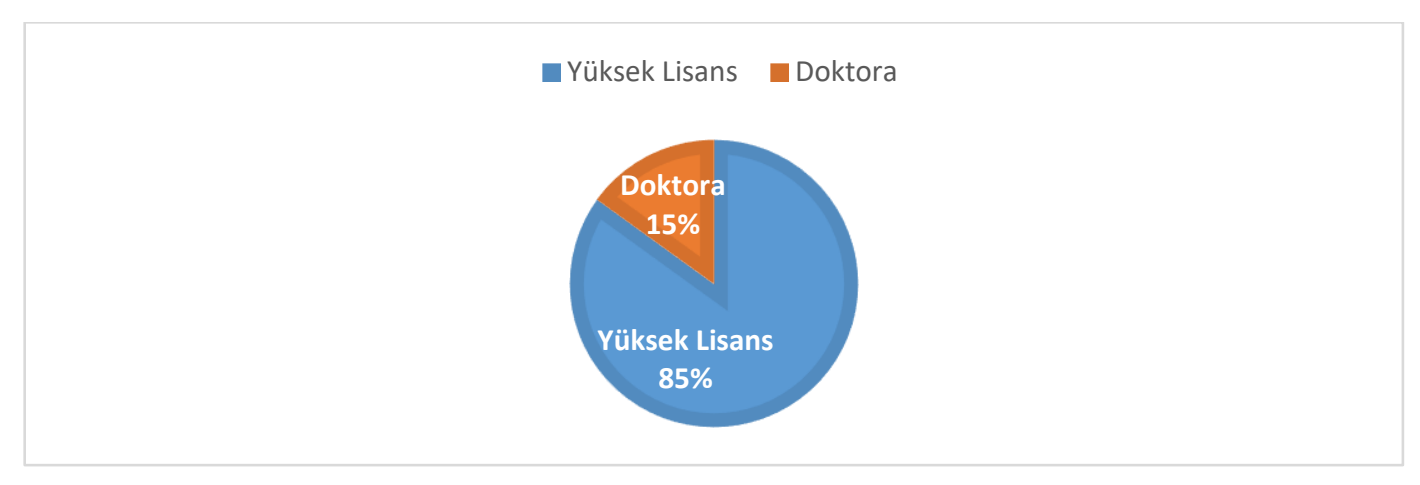

Veri tabanında Eğitim ve Öğretim konu başlığı içerisinde yer alan ve tez adında drama sözcüğü geçen tezler incelendiğinde, tezlerin $\% 85^{\prime}$ inin ( $f=328$ ) yüksek lisans, \%15'inin ( $f=58$ ) ise doktora tezi olduğu görülmektedir. Bu grafik, drama alanında yapılan tezlerin yüksek lisans üzerinde yoğunlaştığını göstermektedir.

Grafik 2. Eğitim ve öğretim konu başığı içerisinde taranan drama tezlerinin yıllara göre dağııımı

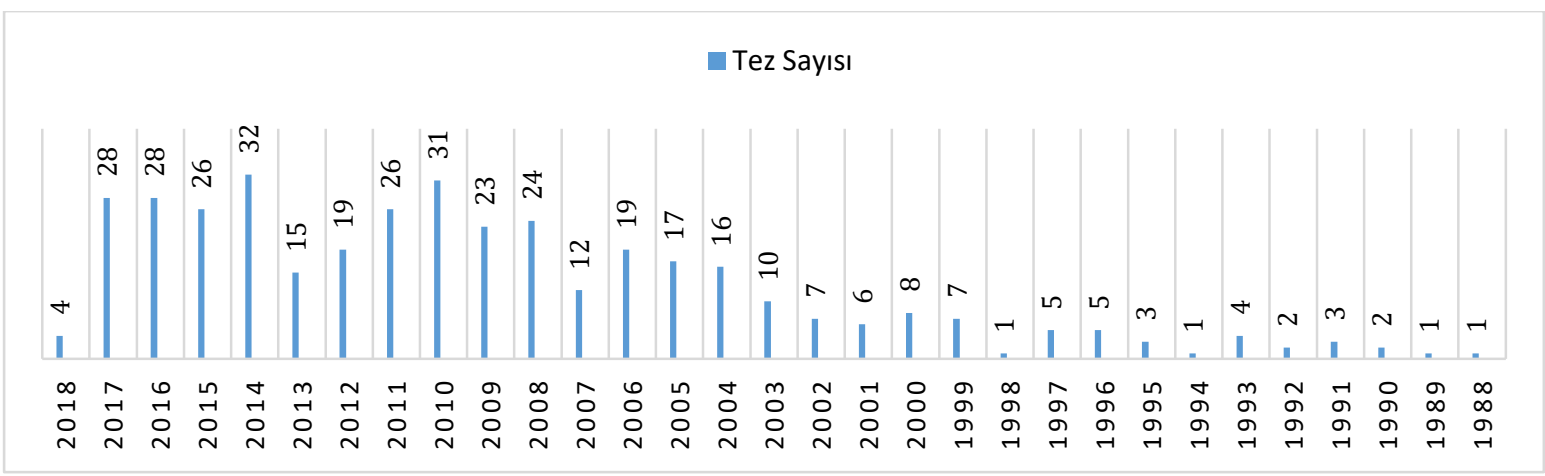

Grafik 2 incelendiğinde drama alanında yapılan ilk tezlerin 1990 öncesinde olduğu, alanda en fazla tezin 2010 ve 2014 yıllarında yapıldığı, tez sayılarında zaman zaman azalmalar görülmesine rağmen her sene konu ile ilgili çalışmalar yapıldığı görülmektedir. 
Grafik 3. Eğitim ve öğretim konu başlığı içerisinde taranan drama tezlerinin üniversitelere göre dağılımı

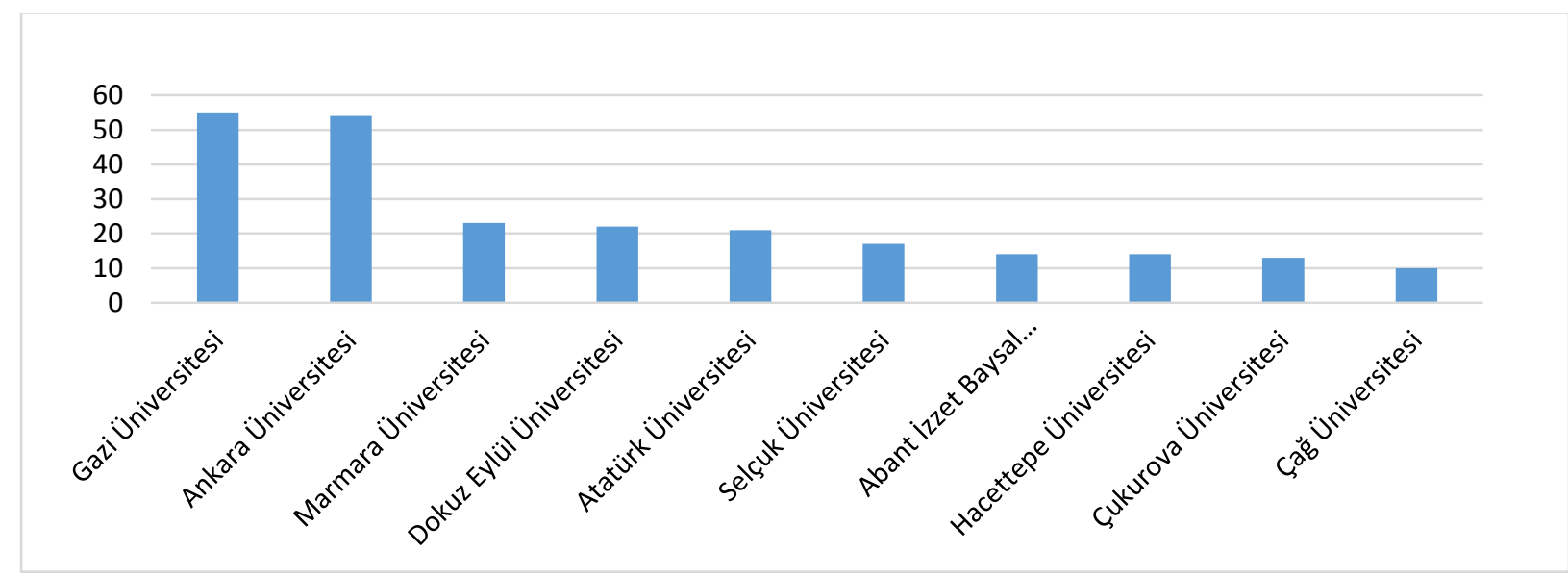

Grafik 3'te Eğitim ve Öğretim konu başlığı içerisinde drama ile ilgili tezlerin en çok Gazi Üniversitesi ( $f=55, \% 14,2)$ ve Ankara Üniversitesi ( $f=54, \% 13,9)$ bünyesinde yapıldığı görülmektedir. Grafikte yer alan üniversiteler dışında 54 devlet, 9 vakıf üniversitesi bünyesinde de çalışmalar yapıldığı tespit edilmiştir.

Grafik 4. Eğitim ve öğretim konu başlığı içerisinde taranan drama tezlerinin ana bilim dallarına göre dağılımı

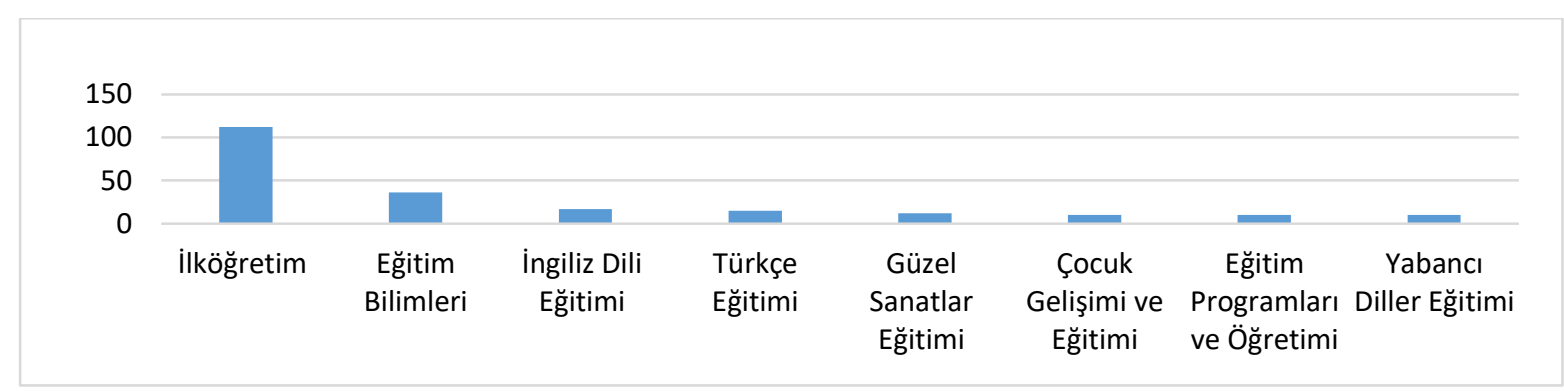

Grafik 4'e bakıldığında drama tezlerinin en çok ilköğretim ana bilim dalı $(f=112, \% 29,01)$ içerisinde yapıldığı görülmektedir. Sırasıyla eğitim bilimleri $(f=36, \% 9,3)$, İngiliz dili eğitimi ( $f=17$, $\% 4,4)$, Türkçe eğitimi ( $f=15, \% 3,8)$ alanda en çok araştırma yapılan ana bilim dalları olarak tespit edilmiştir. Grafikte belirtilenlerin dışında, 52 ana bilim dalında konu ile ilgili çalışmalar yapıldığı görülmüştür. Bunun yanı sıra ana bilim dalı belirtilmeyen $64(\% 16,5)$ tez olduğu görülmüştür.

Eğitim ve Öğretim konu başlığı içerisinde yer alan drama tezlerinin, ana bilim dalları kadar enstitü türünde de çeşitlilik gösterdiği tespit edilmiştir. 
Türkçe Eğitimi Konularını Temel Alan Drama Çalışmalarına Yönelik Bir İnceleme

Grafik 5. Eğitim ve öğretim konu başlığı içerisinde taranan drama tezlerinin enstitülere göre dağılımı

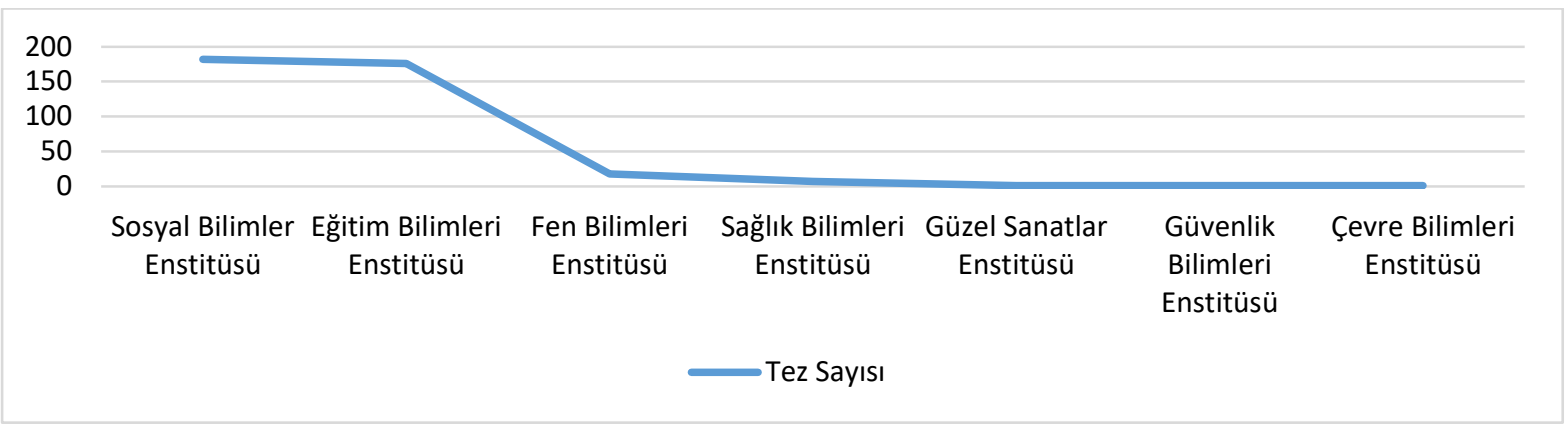

Grafik 5'te yer alan verilere bakıldığında drama tezlerinin en çok sosyal bilimler ( $\mathrm{f}=181$, $\% 46,8)$ ve eğitim bilimleri $(f=176, \% 45,5)$ enstitülerinde yapıldığı görülmektedir. Fen bilimleri $(f=19$, $\% 4,9)$ ve sağlık bilimleri $(f=7, \% 1,81)$ enstitülerinin yanı sıra güzel sanatlar, çevre bilimleri ve güvenlik bilimleri enstitülerinde de taranan birer tez $(f=1, \% 0,25)$ tespit edilmiştir

Grafik 6. Eğitim ve öğretim konu başlığı içerisinde taranan drama tezlerinin erişim durumları

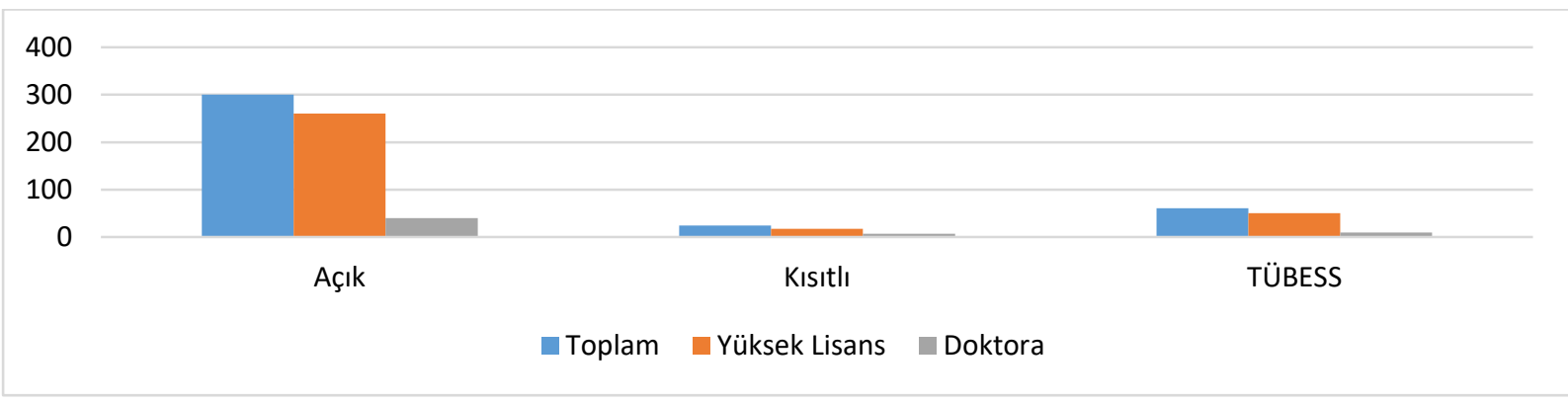

Eğitim ve Öğretim konu başlığı içerisinde taranan 300 tezin, erişime açık olduğu görülmüştür. Bu tezlerin 260’ı $(\% 86,6)$ yüksek lisans, 40’ı $(\% 13,3)$ doktora tezidir. Veri tabanında yapılan taramada, belirtilen konu başlığı içerisinde 25 tezin araştırmacılar tarafından kısıtlandığı görülmüştür. Bu tezlerden 18'i (\%72) yüksek lisans, 7’si (\%28) doktora tezidir. 61 tezin ise veri tabanında yayınlanma izni bulunmamaktadır. Bu tezlerin 51'i $(\% 83,6)$ yüksek lisans, 10’u $(\% 16,39)$ doktora tezidir.

Çalışmanın örneklemine dâhil edilen tezler, evrenin \%7,77'sini ( $f=30)$ oluşturmaktadır. Örneklem içerisinde yer alan tezlerin $\% 86,6^{\prime}$ sı $(f=26)$ yüksek lisans, $\% 13,3^{\prime} \ddot{u}(f=4)$ ise doktora tezidir. 
Grafik 7. Türkçe eğitimini konu alan drama tezlerinin yıllara göre dağıımı

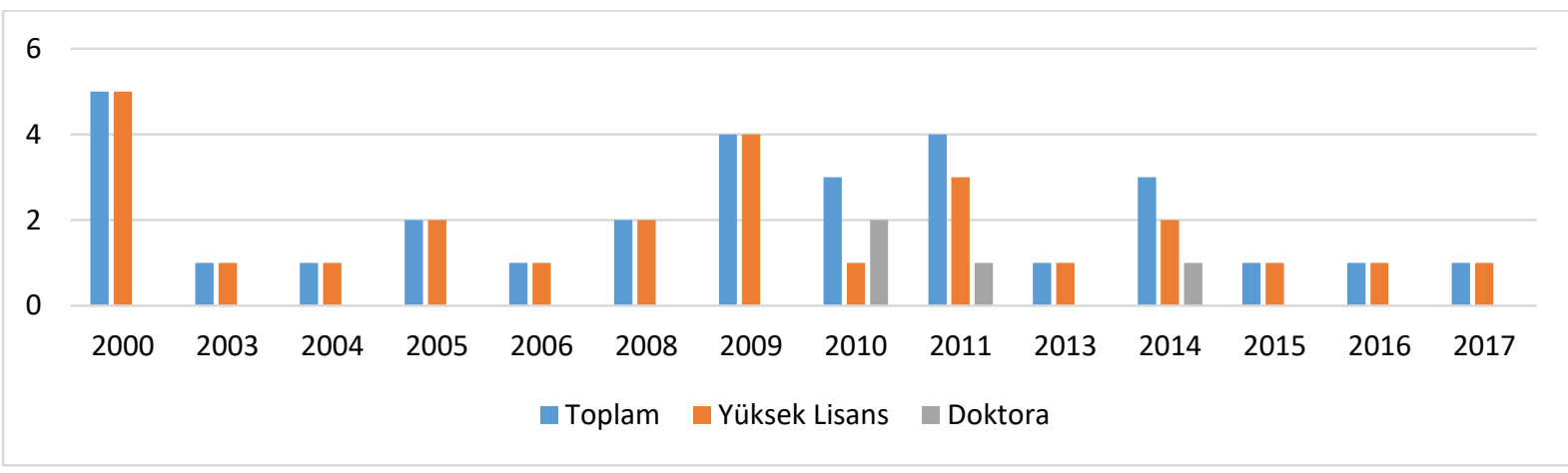

Türkçe eğitimi konularında dramaya yönelik yapılan tez çalışmalarının 2000 yılı itibarıyla başladığı ve en fazla tezin de belirtilen yıl içerisinde yayımlandığı görülmektedir. 2009 ve 2011 yıllarında alandaki tez çalışmaları artmış, sonraki yıllarda ise tez sayısında azalma görülmesine rağmen her yıl konu ile ilgili en az 1 çalışmanın yapıldığı tespit edilmiştir. Alandaki ilk doktora çalışmaları 2010 yılında tamamlanmış, 2015 yılı itibarıyla ise alanda yapılmış bir doktora tezine rastlanılmamıştır. Grafikte yer alan verilere bakıldığında, drama konusunda Türkçe eğitimi alanındaki çalışmaların sayı bakımından yetersiz olduğu düşünülmektedir.

Grafik 8. Örnekleme dâhil edilen tezlerin üniversitelere göre dağılımı

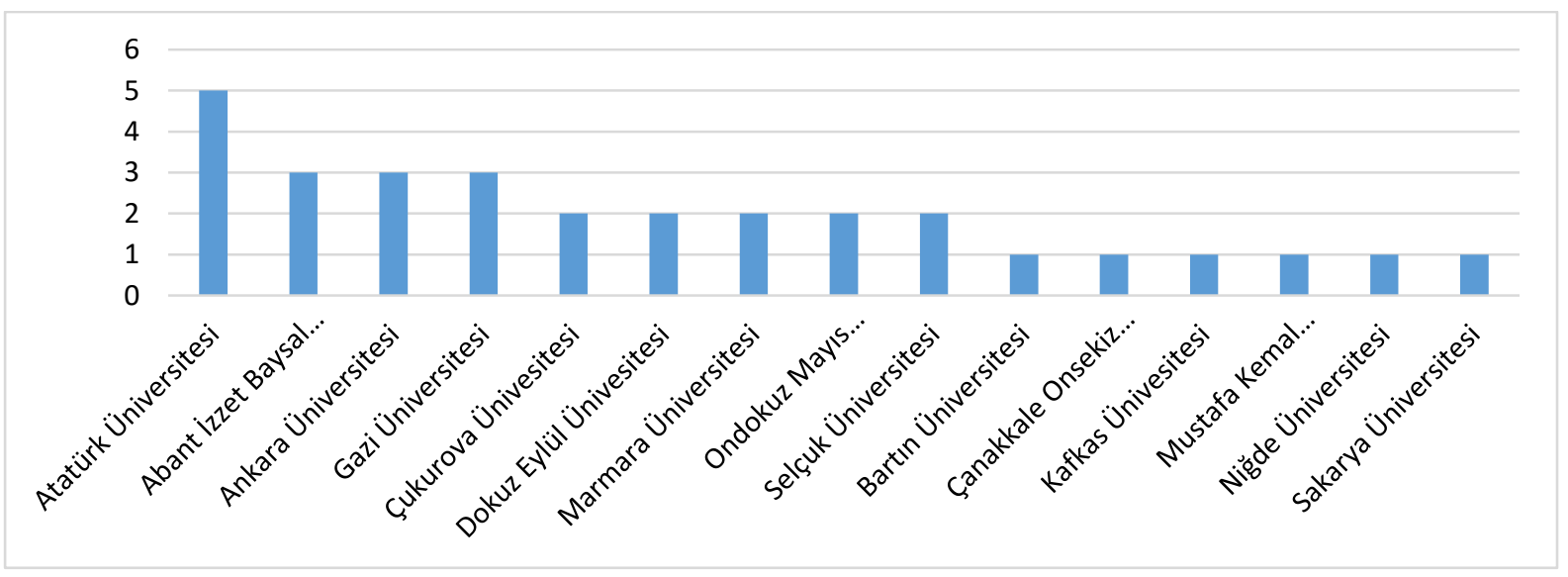

Grafik 8 incelendiğinde, Türkçe eğitimini konu alan drama tezlerinin en çok Atatürk Üniversitesi ( $f=5$ ) bünyesinde yapıldığı görülmektedir. Abant İzzet Baysal, Ankara ve Gazi Üniversitesi içerisinde tamamlanan üçer tez de araştırmada incelenmiştir. Grafikte yer alan verilere bakılarak alanda yapılan çalışmaların üniversite bazında çeşitlilik gösterdiği görülmektedir.

Türkçe eğitimi konu alanı içerisinde yapılan drama tezlerinin incelenmesi sonucunda tezler; betimsel çalışmalar, dil becerileri üzerinde yöntemin etkililiğini araştıran çalışmalar, yöntemin öğrenci başarısına etkisini ölçen çalışmalar, yöntemin uygulanma yeterliliğine ilişkin çalışmalar ve Türkçe dersi kapsamında sınırlandırılmış konulara yönelik çalışmalar olmak üzere beş başlık altında incelenmiştir. 
Türkçe Eğitimi Konularını Temel Alan Drama Çalışmalarına Yönelik Bir İnceleme

Türkçe eğitimi konularına yönelik, drama tezleri ilk yıllarda daha çok betimsel çalışmalar olarak temellendirilmiştir.

Tablo 1. Türkçe eğitimi konularında yapılan betimsel drama çalışmaları

\begin{tabular}{|c|c|c|c|}
\hline Araştırmacı & Tez Adı & Üniversite & Yöntem / İşlemler \\
\hline $\begin{array}{l}\text { Tümtürk } \\
\text { Yılmaz, } 2000\end{array}$ & $\begin{array}{l}\text { Türkçe } \\
\text { öğretiminde } \\
\text { yaratıcı drama } \\
\text { yöntemi ile } \\
\text { diksiyon becerileri } \\
\text { kazandırmaya } \\
\text { ilişkin bir model } \\
\text { önerisi yaklaşımı }\end{array}$ & $\begin{array}{c}\text { Ankara } \\
\text { Üniversitesi }\end{array}$ & $\begin{array}{l}\text { - Çalışmada } 4 \text {. ve } 5 \text {. sınıf seviyelerine yönelik, } \\
\text { her iki sınıf seviyesi için } 36 \text { saatlik diksiyon ders } \\
\text { programı örneği yer almaktadır. }\end{array}$ \\
\hline Kara, 2000 & $\begin{array}{l}\text { Türkçe } \\
\text { öğretiminde } \\
\text { yaratıcı drama }\end{array}$ & $\begin{array}{c}\text { Atatürk } \\
\text { Üniversitesi }\end{array}$ & $\begin{array}{l}\text { - Yaratıcı drama kavramının açıklanması, } \\
\text { eğitimde kullanılması ve Türkçe öğretimi ile } \\
\text { ilişkisine yer verilmiş, Türkçe dersinde } \\
\text { uygulanabilecek drama planları sunulmuştur. }\end{array}$ \\
\hline Akar, 2000 & $\begin{array}{l}\text { Temel eğitimin } \\
\text { ikinci aşamasında } \\
\text { drama yöntemi ile } \\
\text { Türkçe öğretimi: } \\
\text { Dorothy } \\
\text { Heathcote'un } \\
\text { "Uzman Rolü } \\
\text { Yaklaşımı" }\end{array}$ & $\begin{array}{l}\text { Çukurova } \\
\text { Üniversitesi }\end{array}$ & $\begin{array}{l}\text { - Temel eğitimin ikinci aşamasında Türkçe dersi } \\
\text { sözlü anlatım becerilerinin geliştirilmesine } \\
\text { yönelik drama ders planı örnekleri } \\
\text { hazırlanmıştır. } \\
\text { - Dorothy Heathcote'un drama çalışmasının } \\
\text { videoları izlenerek hem liderin hem de } \\
\text { öğrencilerin kullandıkları sözlü anlatım } \\
\text { becerileri analiz edilmiştir. }\end{array}$ \\
\hline Serin, 2005 & $\begin{array}{l}\text { Yaratıcı dramayla } \\
\text { kurgulanmış } \\
\text { yaratıcı yazma } \\
\text { çalışmalarına ilişkin } \\
\text { bir model önerisi }\end{array}$ & $\begin{array}{c}\text { Ankara } \\
\text { Üniversitesi }\end{array}$ & $\begin{array}{l}\text { - Türk Dili ve Edebiyatı dersi kapsamında } 11 . \\
\text { sınıflara uygulanabilecek her biri } 120 \\
\text { dakikadan oluşan } 5 \text { eğitim } \\
\text { oluşturulmuştur. }\end{array}$ \\
\hline
\end{tabular}

Türkçe eğitimi konularında drama alanında yapılan betimsel çalışmaların, belirtilen alanda yapılan ilk çalışmalar arasında yer aldığı görülmektedir. Tümtürk Yılmaz (2000) tarafından yapılan çalışmada dil, dilin gelişimi, diksiyon ve diksiyon eğitimi üzerinde durulmuştur. Ardından yaratıcı drama ve eğitimde drama kavramları açıklanmıştır. Yaratıcı drama liderinin taşıması gereken nitelikler belirtildikten sonra model önerisinin hedef kitlesi olan 4. ve 5. sınıf öğrencilerinin dil gelişim özelliklerine yer verilmiştir. Kara (2000), Türkçe öğretiminde kullanılan anlatım, soru-cevap ve tartışma yöntemlerinin eksikliklerine ve yararlarına yer verdikten sonra Türkçe öğretimi ile yaratıcı drama yönteminin ilişkisini ortaya koymuştur. Drama liderliği, araç-gereçleri ve oyun alanı ile dramanın öğretim ilkelerine yer verildikten sonra şiir ve hikâye türlerine yönelik dramatizasyon örnekleri sunulmuştur. Tez çalışmasının 5. bölümünde ise Türkçe dersi kapsamında uygulanabilecek drama planlarına yer verilmiştir. Bu çalışma hem drama hem de dramatizasyon çalışmalarına yer vermektedir. Akar (2000), Dorothy Heathcote'un drama çalışmalarında kullandığı sözlü anlatım becerilerini analiz etmiştir. Uygulayıcının kullandığı sözel dil becerileri soru sorma, bilgi verme, açıklama yapma; öğrencilerin kullandığı sözel dil becerileri ise soru sorma, açıklama yapma, tahmin etme, tartışma olarak tespit edilmiştir. Serin (2005), geleneksel yazma çalışmalarının yaratıcı 
dramayla bütünleştirilmiş yaratıcı yazma çalışmalarına dönüştürülmesinin Türk Dili ve Edebiyatı dersinin amaçlarına ulaşmasında katkı sağlayacağı belirtmiş ve bir model önerisi sunmuştur.

Tablo 2. Dil becerileri üzerinde yöntemin etkililiğini araştıran çalışmalar

\begin{tabular}{|c|c|c|c|}
\hline Araştırmacı & Tez Adı & Üniversite & Yöntem / İşlemler \\
\hline Karakuş, 2000 & $\begin{array}{l}\text { Drama yönteminin } \\
\text { ilköğretim beşinci sınıf } \\
\text { öğrencilerinin öykü } \\
\text { yazma becerilerine } \\
\text { etkisi }\end{array}$ & $\begin{array}{l}\text { Çukurova } \\
\text { Üniversitesi }\end{array}$ & $\begin{array}{l}\text { - Ön test-son test kontrol gruplu model } \\
\text { - 5. sınıf öğrencileri ile } 15 \text { hafta Öykü Yazma } \\
\text { Programı uygulanmıştır. }\end{array}$ \\
\hline Yazkan, 2000 & $\begin{array}{l}\text { Ilköğretim okullarının } \\
\text { 1. kademesinde } \\
\text { dinlediğini anlama } \\
\text { davranışının } \\
\text { kazandırılmasına } \\
\text { dramatizasyonun etkisi }\end{array}$ & $\begin{array}{c}\text { Marmara } \\
\text { Üniversitesi }\end{array}$ & $\begin{array}{l}\text { - Deneme modeli } \\
\text { - Üç farklı okuldaki 3. ve 4. sınıflarla, birer hikâye } \\
\text { metni kullanılarak, dinlediğini anlama becerisine } \\
\text { dramatizasyonun etkisi üzerine çalışılmıştır. }\end{array}$ \\
\hline Köklü, 2003 & $\begin{array}{l}\text { Türkçe öğretiminde } 7 . \\
\text { ve } 8 \text {. sınıf öğrencilerine } \\
\text { dinlediğini anlama } \\
\text { davranışının } \\
\text { kazandırımasına } \\
\text { dramatizasyonun etkisi }\end{array}$ & $\begin{array}{c}\text { Marmara } \\
\text { Üniversitesi }\end{array}$ & $\begin{array}{l}\text { - Deneme modeli } \\
\text { - 7. sınıflara bir şiir, 8. sınıflara ise bir öykü } \\
\text { dramatizasyonla aktarılmış; deney ve kontrol } \\
\text { grupları arasındaki farka bakılmıştır. }\end{array}$ \\
\hline $\begin{array}{l}\text { Karateke, } \\
2006\end{array}$ & $\begin{array}{l}\text { Yaratıcı dramanın } \\
\text { ilköğretim II. kademede } \\
\text { 6. sınıf öğrencilerinin } \\
\text { yazılı anlatım } \\
\text { becerilerine olan etkisi }\end{array}$ & $\begin{array}{l}\text { Mustafa } \\
\text { Kemal } \\
\text { Üniversitesi }\end{array}$ & $\begin{array}{l}\text { - Ön test-son test kontrol gruplu deneme modeli } \\
\text { - } 6 . \text { sınıflar ile yapılan yaratıcı drama } \\
\text { çalışmalarının yazılı anlatıma kelime/cümle, } \\
\text { hece/cümle, morfem/cümle, hece/kelime, } \\
\text { morfem/kelime, hece/morfem oranı açısından } \\
\text { etkisine bakılmıştır. }\end{array}$ \\
\hline $\begin{array}{l}\text { Kaya Güler, } \\
2008\end{array}$ & $\begin{array}{l}\text { İlköğretim dördüncü } \\
\text { sınıf Türkçe dersinde } \\
\text { yaratıcı drama } \\
\text { yönteminin etkililiği }\end{array}$ & $\begin{array}{l}\text { Ondokuz } \\
\text { Mayıs } \\
\text { Üniversitesi }\end{array}$ & $\begin{array}{l}\text { - Kontrol kümeli ön test-son test tasarımı } \\
\text { - 4. sınıflar ile yapılan } 18 \text { haftalık yaratıcı drama } \\
\text { uygulamalarının okuduğunu anlama ve anladığını } \\
\text { yazıyla anlatma üzerindeki etkisine bakılmıştır. }\end{array}$ \\
\hline Koç, 2009 & $\begin{array}{l}\text { Ilköğretim 7. sınıf } \\
\text { Türkçe dersinde } \\
\text { dramatizasyonla } \\
\text { yaratıcı dramanın } \\
\text { karşılaştırılması }\end{array}$ & $\begin{array}{l}\text { Ondokuz } \\
\text { Mayıs } \\
\text { Üniversitesi }\end{array}$ & $\begin{array}{l}\text { - Kontrol kümeli ön test-son test modeli } \\
\text { - 7. sınıflarda okuduğunu anlama ve anladığını } \\
\text { yazıyla anlatma becerilerinin gelişiminde yaratıcı } \\
\text { drama yöntemi ile dramatizasyon yönteminin } \\
\text { etkisi karşılaştırılmıştır. } 20 \text { saat süren uygulamada } \\
\text { deney grubunda yaratıcı drama, kontrol grubunda } \\
\text { ise dramatizasyon temel alınmıştır. }\end{array}$ \\
\hline Kara, 2010 & $\begin{array}{l}\text { Dramayla öykü } \\
\text { oluşturma yönteminin } \\
\text { ilköğretim ikinci } \\
\text { kademe Türkçe } \\
\text { öğretimine etkisi }\end{array}$ & $\begin{array}{c}\text { Selçuk } \\
\text { Üniversitesi }\end{array}$ & $\begin{array}{l}\text { - Yarı deneysel, kontrol gruplu ön test-son test } \\
\text { - Dramayla öykü oluşturma yöntemine yönelik } \\
\text { öğretmen, öğrenci anketi ve öğretmen görüşme } \\
\text { formu tarama modeliyle yapılandırılmıştır. } \\
\text { - 6, } 7 \text { ve } 8 \text {. sınıflarda dramayla öykü oluşturmaya } \\
\text { yönelik } 8 \text { hafta uygulamalar yapılmış, yöntemin } \\
\text { öğrencilerin Türkçe dersine olan tutumuna } \\
\text { etkisine bakılmış ve süreç ile ilgili öğrenci görüşleri } \\
\text { alınmıştır. }\end{array}$ \\
\hline Türkel, 2011 & $\begin{array}{l}\text { Yaratıcı dramanın } \\
\text { yaratıcı yazma } \\
\text { başarısına ve yazmaya } \\
\text { karşı tutuma etkisi: } \\
\text { ilköğretim 8. sınıf }\end{array}$ & $\begin{array}{l}\text { Dokuz Eylül } \\
\text { Üniversitesi }\end{array}$ & $\begin{array}{l}\text {-Ön test-son test kontrol gruplu deneme modeli } \\
\text { - 8. sınıflarda } 12 \text { hafta, } 24 \text { saat yürütülen drama } \\
\text { etkinliklerinin yaratıcı yazma ve yazmaya yönelik } \\
\text { tutuma etkisi incelenmiştir. }\end{array}$ \\
\hline Özcan, 2013 & $\begin{array}{l}\text { Yaratıcı dramanın } \\
\text { anlayarak anlatma }\end{array}$ & $\begin{array}{c}\text { Gazi } \\
\text { Üniversitesi }\end{array}$ & $\begin{array}{l}\text { - Kontrol gruplu ön test-son test deneysel desen } \\
\text { - } 6 \text {. sınıflar ile } 5 \text { hafta süren uygulamaların okuma }\end{array}$ \\
\hline
\end{tabular}




\begin{tabular}{|c|c|c|c|}
\hline & $\begin{array}{c}\text { becerilerinin } \\
\text { geliştirilmesine etkisi }\end{array}$ & & $\begin{array}{l}\text { / dinleme, konuşma ve yazma becerilerine etkisi } \\
\text { araştırılmıştır. }\end{array}$ \\
\hline Uysal, 2014 & $\begin{array}{l}\text { Dinleme ve konuşma } \\
\text { becerilerinin } \\
\text { kazandırılmasında } \\
\text { yaratıcı drama temelli } \\
\text { bir model önerisi }\end{array}$ & $\begin{array}{c}\text { Gazi } \\
\text { Üniversitesi }\end{array}$ & $\begin{array}{l}\text { - Karma yöntem } \\
\text {-Araştırmanın nicel boyutunda ön test-son test } \\
\text { kontrol gruplu model, nitel boyutunda ise } \\
\text { görüşme ve doküman analizi kullanılmıştır. } \\
\text { - 7. sınıflarda } 14 \text { hafta, } 56 \text { saat uygulanan yaratıcı } \\
\text { drama etkinliklerinin dinleme ve konuşma } \\
\text { becerileri üzerindeki etkisi incelenmiş; } \\
\text { öğrencilerin süreçalgıları tespit edilmiştir. }\end{array}$ \\
\hline Peker, 2015 & $\begin{array}{c}\text { Yazılı anlatım } \\
\text { becerilerinin } \\
\text { geliştirilmesinde } \\
\text { yaratıcı drama } \\
\text { tekniklerinden özel } \\
\text { mülkiyet tekniğinin } \\
\text { yaratıcı yazma } \\
\text { yaklaşımı ile } \\
\text { karşılaştırılması }\end{array}$ & $\begin{array}{c}\text { Ankara } \\
\text { Üniversitesi }\end{array}$ & $\begin{array}{l}\text { - Nitel araştırma } \\
\text { - Öğrencilerin araştırma öncesi ve sonrası ile } \\
\text { araştırma sürecinde ürettikleri yazılı ürünler } \\
\text { betimsel analiz; odak grup görüşmeleri içerik } \\
\text { analizi ile incelenmiştir. } \\
\text { - 4. sınıflarda deney grubunda yaratıcı drama, } \\
\text { kontrol grubunda yaratıcı yazma çalışmaları } 24 \\
\text { saat sürdürülmüş. }\end{array}$ \\
\hline Erden, 2016 & $\begin{array}{l}\text { Drama ve işbirlikli } \\
\text { öğrenme yöntemlerinin } \\
5 . \text { sınıf öğrencilerinin } \\
\text { okuduğunu anlama } \\
\text { becerilerine, tutuma ve } \\
\text { kalıcılığa etkileri }\end{array}$ & $\begin{array}{l}\text { Abant İzzet } \\
\text { Baysal } \\
\text { Üniversitesi }\end{array}$ & $\begin{array}{l}\text { - Ön-test son-test kontrol gruplu gerçek deneysel } \\
\text { desen } \\
\text { - } 36 \text { saat süren uygulamalarda, } 5 \text {. sınıflarda iş } \\
\text { birlikli öğrenme ortamı ve dramayla öğrenme } \\
\text { ortamı oluşturulan iki deney grubu ile geleneksel } \\
\text { öğrenme ortamının kullanıldığı kontrol grubunun } \\
\text { okuduğunu anlama becerileri ve okumaya yönelik } \\
\text { tutumları karşılaştırılmıştır. }\end{array}$ \\
\hline Pat, $2017^{1}$ & $\begin{array}{l}\text { Illkokul 3. sınıf Türkçe } \\
\text { dersinde yaratıcı drama } \\
\text { yönteminin konuşma } \\
\text { becerilerini } \\
\text { geliştirmeye etkisi }\end{array}$ & $\begin{array}{c}\text { Bartın } \\
\text { Üniversitesi }\end{array}$ & $\begin{array}{l}\text {-Ön test-son test kontrol gruplu yarı deneysel } \\
\text { desen } \\
\text { - 3. sınıflar ile } 6 \text { hafta boyunca deney grubunda } \\
\text { yaratıcı drama, kontrol grubunda mevcut öğretim } \\
\text { programına göre sürdürülen derslerin konuşma } \\
\text { becerisine etkisi araştırılmıştır. }\end{array}$ \\
\hline
\end{tabular}

Türkçe eğitiminin temel konuları olan dil becerilerini ele alan tezler, tabloda belirtildiği üzere genellikle kontrol gruplu ön test-son test deneysel desen şeklinde planlanmıştır. Yazma becerisi çalışmalarında (Karakuş, 2000; Karateke, 2006; Peker, 2015) 4, 5 ve 6. sınıf seviyelerinde yüksek lisans çalışmaları, 8. sınıf seviyesinde bir doktora çalışması (Türkel, 2011) olduğu görülmektedir. Dinleme becerisi alanında (Köklü, 2003; Yazkan, 2000) 3. ve 4. sınıflar ile 7. ve 8. sınıflar seviyelerinde çalışmalar mevcuttur. Okuma becerisinde (Erden, 2016) 5. sınıf, konuşma becerisinde ise (Pat, 2017) 3. sınıf seviyesinde çalışmalar bulunmaktadır. Tek dil becerisi üzerine yoğunlaşan çalışmaların yanında birden fazla dil becerisini ele alan çalışmalar da tespit edilmiştir. Okuduğunu anlama ve anladığını yazıyla anlatma konusunda 4. ve 7. sınıflar seviyesinde iki çalışma (Kaya Güler, 2008; Koç, 2009); 7. sınıf seviyesinde dinleme ve konuşma becerilerini ele alan bir doktora tezi (Uysal, 2014) bulunmaktadır. Ayrıca dramanın tüm dil becerilerine etkisini 6, 7 ve 8 . sınıf seviyelerinde araştıran bir doktora (Kara, 2010), 6. sınıf seviyesinde araştıran bir yüksek lisans tezi (Özcan, 2013) bulunmaktadır.

\footnotetext{
${ }^{1}$ Araştırmacının tez çalışması kısıtlı olduğundan sınıflandırma aşamasında tezin veri tabanında yer alan özet metninden yararlanılmıştır.
} 
Tablo 3. Yöntemin öğrenci başarısına etkisini ölçen çalışmalar

\begin{tabular}{|c|c|c|c|}
\hline Araştırmacı & Tez Adı & Üniversite & Yöntem / İşlemler \\
\hline Ünsal, 2005 & $\begin{array}{l}\text { Ilköğretim ikinci } \\
\text { kademe }(6,7,8 . \\
\text { sınıflar) Türkçe } \\
\text { dersinde drama } \\
\text { yönteminin } \\
\text { çocukların dil ve } \\
\text { anlatım } \\
\text { becerilerine katkısı }\end{array}$ & Gazi Üniversitesi & $\begin{array}{l}\text { - 6, } 7 \text { ve 8. sınıflar } \\
\text { - Okuduğunu anlama ve genel bilgi testi ile } \\
\text { öğretmen ve öğrenci görüşlerini almak üzere } \\
\text { anket uygulanmıştır. } \\
\text { - Öğrencilerin bilgi düzeyinde yöntemin } \\
\text { etkililiğine bakılmıştır. }\end{array}$ \\
\hline $\begin{array}{l}\text { Selmanoğlu, } \\
2009\end{array}$ & $\begin{array}{l}\text { illköğretim } 5 . \text { sınıf } \\
\text { Türkçe dersinde } \\
\text { yaratıcı dramanın } \\
\text { öğrenci başarısına } \\
\text { etkisi }\end{array}$ & $\begin{array}{l}\text { Abant İzzet Baysal } \\
\text { Üniversitesi }\end{array}$ & $\begin{array}{l}\text { - Ön test-son test kontrol gruplu deneme modeli } \\
\text { - 5. sınıflarda } 8 \text { ders, } 16 \text { saat uygulanan yaratıcı } \\
\text { drama etkinliklerinin Türkçe Başarı Testi } \\
\text { üzerindeki etkisine bakılmıştır. }\end{array}$ \\
\hline Karacil, 2009 & $\begin{array}{l}\text { Ilköğretim } 1 . \\
\text { kademede yaratıcı } \\
\text { drama yönteminin } \\
\text { öğrencinin } \\
\text { akademik } \\
\text { başarısına etkisi }\end{array}$ & $\begin{array}{c}\text { Kafkas } \\
\text { Üniversitesi }\end{array}$ & $\begin{array}{l}\text { - Deneme modeli } \\
\text { - 5. sınıflarda } 4 \text { hafta } 12 \text { ders saati yürütülen } \\
\text { yaratıcı drama etkinliklerinin, başarı testi ile } \\
\text { öğrenciler üzerindeki etkisine bakılmıştır. }\end{array}$ \\
\hline Maden, 2010 & $\begin{array}{l}\text { İlköğretim } 6 . \text { sınıf } \\
\text { Türkçe dersinde } \\
\text { drama yönteminin } \\
\text { temel dil } \\
\text { becerilerinin } \\
\text { kazanımına etkisi } \\
\text { (Sevgi teması } \\
\text { örneği) }\end{array}$ & $\begin{array}{c}\text { Atatürk } \\
\text { Üniversitesi }\end{array}$ & $\begin{array}{l}\text { - Ön test-son test kontrol gruplu yarı deneysel } \\
\text { desen } \\
\text { - 6. sınıflar ile } 7 \text { hafta süren etkinliklerin okuma, } \\
\text { dil bilgisi, dinleme, konuşma ve yazma başarısı } \\
\text { üzerindeki etkisine bakılmıştır. Deney grubuna, } \\
\text { drama yöntemine yönelik tutum ölçeği } \\
\text { uygulanmıştır. }\end{array}$ \\
\hline Nurses, 2014 & $\begin{array}{l}\text { 7. sınıf Türkçe } \\
\text { dersinde drama } \\
\text { yöntemini } \\
\text { kullanmanın } \\
\text { öğrenci başarısına } \\
\text { etkileri }\end{array}$ & $\begin{array}{c}\text { Atatürk } \\
\text { Üniversitesi }\end{array}$ & $\begin{array}{l}\text { - Ön test-son test kontrol gruplu desen } \\
\text { - 7. sınıflar ile } 3 \text { hafta yürütülen çalışmaların } \\
\text { etkisi Drama Yöntemi Başarı Testi ile } \\
\text { belirlenmeye çalışılmıştır. }\end{array}$ \\
\hline
\end{tabular}

Yukarıdaki tabloda yer alan bilgilere bakıldığında, bu sınıflandırma içerisinde yer alan tezlerin Türkçe dersi konusunda daha bütüncül yaklaşma eğiliminde oldukları, dil becerilerinin geliştirilmesinin yanı sıra öğrenci başarısının ölçülmesini amaçladıkları görülmektedir. Bu yaklaşımda olan tezlerin de 5, 6, 7 ve 8. sınıf seviyelerinde çalışmalar yaptıkları ve farklı sınıf düzeylerinde drama yönteminin başarıya etkisinin irdelendiği görülmektedir. Bu sınıflandırma içerisinde yöntemin 6. sınıf seviyesinde öğrenci başarısına etkisini araştıran bir doktora tezi (Maden, 2010) bulunmaktadır. Tabloda yer alan çalışmalarda genellikle bilgi düzeyindeki değişimi görmeye yönelik ölçme araçlarının tercih edildiği görülmektedir.

Tablo 4. Yöntemin uygulama yeterliğine ilişkin çalışmalar

\begin{tabular}{lcll}
\hline Araştırmacı & Tez Adı & Üniversite & Yöntem / İşlemler \\
\hline Tutuman, 2011 & Türkçe & Dokuz Eylül & - Betimsel yöntem, tarama modeli \\
& $\begin{array}{c}\text { öğretmenlerinin } \\
\text { yaratıcı drama } \\
\text { uygulama }\end{array}$ & Üniversitesi & - İzmir'de görev yapan 131 Türkçe \\
& & öğretmeni ile görüşme yapılmış ve \\
& & öğretmenlere Yaratıcı Drama Yeterlilik \\
\hline
\end{tabular}




\begin{tabular}{ccl}
\hline yeterlilikleri & Anketi uygulanmıştır. \\
\hline Aslan, 2014 Öğretmen & Niğde Üniversitesi & - Betimsel yöntem, tarama modeli \\
& adaylarının yaratıcı & - Eğitim fakültesi sınıf öğretmenliği, sosyal \\
drama yöntemini & bilgiler, Türkçe ve fen bilgisi öğretmen \\
kullanmaya yönelik & adaylarına Yaratıcı Drama Yöntemini \\
öz yeterlik & Kullanmaya Yönelik Öz Yeterlik Algısı \\
algılarının & Ölçeği uygulanmıştır. \\
incelenmesi & \\
\hline
\end{tabular}

Çalışmada ele alınan örneklem içerisinde Türkçe öğretmenlerinin ve öğretmen adaylarının yaratıcı drama yöntemini kullanmaya yönelik yeterlilik algılarını tespit etmeye çalışan 2 yüksek lisans tez çalışması yer almaktadır. Tutuman (2011) tarafından yapılan çalışma doğrudan alanın uygulayıııları olan Türkçe öğretmenlerini ele alırken Aslan (2014) tarafından yapılan çalışma hem veri tabanında Türkçe Eğitimi Ana Bilim Dalı içerisinde yer almasından hem de Türkçe öğretmen adaylarına yönelik bulgular içermesi bakımından çalışmanın çerçevesi içerisinde bulunmaktadır.

Tablo 5. Özelleştirilmiş konulara yönelik çalışmalar

\begin{tabular}{|c|c|c|c|}
\hline Araştırmacı & Tez Adı & Üniversite & Yöntem / İşlemler \\
\hline $\begin{array}{l}\text { Aksoy Tokgöz, } \\
2004\end{array}$ & $\begin{array}{l}\text { İlköğretim } 4 \text {. ve } 5 . \\
\text { sınıf Türkçe } \\
\text { programlarında } \\
\text { edebî türlerden } \\
\text { öykünün } \\
\text { öğretiminde } \\
\text { yaratıcı drama } \\
\text { yönteminin } \\
\text { etkililiği }\end{array}$ & $\begin{array}{c}\text { Çanakkale } \\
\text { Onsekiz Mart } \\
\text { Üniversitesi }\end{array}$ & $\begin{array}{l}\text { - Ön test-son test kontrol gruplu deneme } \\
\text { modeli } \\
\text { - 4. ve } 5 \text {. sınıf öğrencileri ile öykü türünün } \\
\text { öğretimine yönelik } 12 \text { saatlik uygulama } \\
\text { yapılmıştır. }\end{array}$ \\
\hline Kazıcı, 2008 & $\begin{array}{l}\text { Illköğretim ikinci } \\
\text { kademe Türkçe } \\
\text { derslerinde deyim } \\
\text { ve atasözlerinin } \\
\text { öğretiminde } \\
\text { dramatizasyon } \\
\text { yönteminin etkililik } \\
\text { düzeyi }\end{array}$ & $\begin{array}{c}\text { Selçuk } \\
\text { Üniversitesi }\end{array}$ & $\begin{array}{l}\text { - Deneme modeli } \\
\text { - 6. sınıflarda, deney grubunda deyim ve } \\
\text { atasözleri dramatizasyon ile öğretilmiş; } \\
\text { kontrol grubunda ise okunmuş; deney ve } \\
\text { kontrol gruplarının atasözü ve deyimleri } \\
\text { kullanabilme becerileri karşılaştırılmıştır. } \\
\text { Uygulama } 6 \text { hafta sürmüştür. }\end{array}$ \\
\hline Güney, 2009 & $\begin{array}{l}\text { Drama } \\
\text { tekniklerinin } \\
\text { ilköğretim } 4 \text { ve } 5 . \\
\text { sınıflarda kullanımı } \\
\text { (Dede Korkut } \\
\text { hikâyeleri örneği) } \\
\end{array}$ & $\begin{array}{c}\text { Atatürk } \\
\text { Üniversitesi }\end{array}$ & $\begin{array}{l}\text { - Tarama modeli } \\
\text { - 4. ve 5. sınıf seviyelerine uygun olarak Dede } \\
\text { Korkut Hikâyelerinden dokuz destan ile ilgili } \\
\text { öneri etkinlik plan örnekleri hazırlanmış ve } \\
\text { öneri etkinlik plan örnekleri, dokuz farklı } \\
\text { ilköğretim okulunda uygulanmıştır. }\end{array}$ \\
\hline Altıntaş, 2010 & $\begin{array}{l}\text { ilköğretim 4.sınıf } \\
\text { Türkçe ders } \\
\text { kitaplarındaki } \\
\text { metinlerin } \\
\text { işlenişine yönelik } \\
\text { hazırlanan drama } \\
\text { yönelimi eğitim } \\
\text { programının } \\
\text { istenen davranışları } \\
\text { kazandırmaya } \\
\text { etkisi }\end{array}$ & $\begin{array}{c}\text { Sakarya } \\
\text { Üniversitesi }\end{array}$ & $\begin{array}{l}\text { - Ön test-son test kontrol gruplu model } \\
\text { - 4. sınıflara yönelik drama eğilimli davranış } \\
\text { değiştirme programı hazırlanmış ve bu } \\
\text { programın öğrencilerin istendik davranışları } \\
\text { üzerindeki etkisi araştırılmıştır. }\end{array}$ \\
\hline Yeşilyurt, 2011 & 6. sınıflarda yapım & Abant İzzet & -Ön test-son test kontrol gruplu deneysel \\
\hline
\end{tabular}




\begin{tabular}{|c|c|c|c|}
\hline & $\begin{array}{c}\text { eklerinin } \\
\text { öğretimine yaratıcı } \\
\text { drama yönteminin } \\
\text { etkisi }\end{array}$ & $\begin{array}{c}\text { Baysal } \\
\text { Üniversitesi }\end{array}$ & $\begin{array}{l}\text { desen } \\
\text { - 6. sınıflar ile } 6 \text { ders saati yaratıcı drama ile } \\
\text { işlenen derslerin yapım ekleri öğrenme } \\
\text { becerisi üzerindeki etkisi araştırılmıştır. }\end{array}$ \\
\hline Şenol, 2011 & $\begin{array}{c}\text { Deyimlerin yaratıcı } \\
\text { drama yöntemiyle } \\
\text { öğretimi }\end{array}$ & $\begin{array}{c}\text { Atatürk } \\
\text { Üniversitesi }\end{array}$ & $\begin{array}{l}\text { - Inceleme ve gözlemleme modeli } \\
\text { - 7. sınıflar ile drama yöntemi kullanımının, } 10 \\
\text { adet deyimin öğretiminde ve kalıcılığındaki } \\
\text { etkisi araştırılmıştır. }\end{array}$ \\
\hline
\end{tabular}

Türkçe eğitimi içerisinde özelleştirilmiş konulara yönelik drama çalışmaları da bulunmaktadır. Bu çalışmalar, Türkçe eğitiminin temeli olan dil becerilerinin yanı sıra Türkçe dersi kapsamında ele alınan konulara yönelik farklı bir bakış açısı sunmak ve drama yönteminin birçok konunun öğretiminde kullanılabileceğini göstermek açısından önem taşımaktadır. Tür olarak öykünün öğretilmesinin yanı sıra, bir araç metin olarak hikâyelerden yararlanan çalışmalar olduğu da görülmektedir. Deyim ve atasözlerinin canlandırılması, temelinde bir hikâye barındırdığı için Türkçe dersinin amaçlarına da yönelik olmakta; dil bilgisinin drama ile öğretilmesi, çalışmaların farklılığını görmek açısından önem kazanmaktadır.

\section{Tartışma, Sonuç ve Öneriler}

YÖK Ulusal Tez Merkezi veri tabanında, Eğitim ve Öğretim konusu içerisinde yer alan ve başlığında drama sözcüğü bulunan tezlerin incelendiği çalışmada, 386 teze ulaşılmış; tezlerin \%85'inin yüksek lisans, \%15'inin ise doktora tezi olduğu görülmüştür. Bu bulgudan hareketle eğitim alanında yapılan drama tezlerinin yüksek lisans düzeyinde yığıldığı görülmektedir.

Eğitim ve öğretim konusunda yapılan drama tezlerinin yıllara göre dağılımına bakıldığında, tezlerin 1999 yılı itibarıyla gözle görülür bir şekilde arttığı, 2014 yılında ise ( $f=32$ ) en yüksek sayıya ulaştığı görülmektedir. 1999 yılı sonrasında her sene düzenli olarak konuyla ilgili çalışmalar yapılmasının, yöntemin dünyada kabul görmesi, Türkiye'de tanınmaya başlaması ve 2005 yılı sonrasında öğretim programlarının içerisinde yer almasıyla ilişkili olabileceği düşünülmektedir.

Eğitim ve Öğretim konusunda yapılan tezler 56'sı devlet, 9'u vakıf üniversitesi olmak üzere toplam 65 farklı üniversitede gerçekleşmiştir. En çok tez Gazi Üniversitesi ( $f=55$ ) ve Ankara Üniversitesi ( $f=54$ ) bünyesinde yapılmıştır. Bu durumun, iki üniversitenin de dramaya yönelik lisansüstü programlara sahip olması, drama alanında çalışan hocaların bu üniversitelerde yoğunlaşması, Ankara'da drama eğitimi verilen kurumların bulunmasından kaynaklandığı; ayrıca, iki üniversitenin lisansüstü öğrenci sayısının da bu durumu etkilediği düşünülmektedir.

Drama alanında yapılan eğitim tezleri incelendiğinde, yöntemin birçok ana bilim dalında çalışma konusu olarak yer aldığı görülmüştür. Alanda en çok ilköğretim ana bilim dalında ( $f=112)$ çalışma bulunmaktadır. Eğitim bilimlerinin neredeyse her alanında drama çalışmaları mevcuttur. Çalışmalar 60 farklı ana bilim dalı altında toplanmıştır. Ana bilim dallarındaki bu çeşitliliğe, drama ile 
ilgili tüm alanlarda çalışılmasının yanı sıra, ana bilim dallarının isimlerinde karşılaşılan farklılıkların da (örneğin, Türkçe Eğitimi Ana Bilim Dalı, Sosyal Bilgiler ve Türkçe Ana Bilim Dalı, Türkçe Öğretmenliği Ana Bilim Dalı) sebep olabileceği düşünülmektedir.

Drama alanında yapılan lisansüstü tezlerin neredeyse yarısı $(\% 46,8)$ sosyal bilimler enstitüsü bünyesinde gerçekleşmiştir. Alanda, eğitim bilimleri enstitüsü altındaki çalışmaların $(\% 45,5)$ son yıllarda artış gösterdiği de gözlenmiştir.

Araştırmada Eğitim ve Öğretim konu başığında Türkçe eğitimini drama yöntemi ile ele alan tez sayısının ( $f=30 ; \% 7,7)$ düşük olduğu sonucuna ulaşılmıştır. Ütkür (2018), hayat bilgisi dersiyle ilgili yapılan lisansüstü tezleri, kullandıkları yöntem ve etkinlikler açısından incelemiştir. Çalışma sonucunda, hayat bilgisi dersine yönelik yapılan tezlerde en çok drama yöntem ve etkinliklerinin kullanıldığı sonucuna ulaşmıştır. Bu bulgu, farklı disiplinlerde drama yönteminin yoğun olarak çalışıldığını göstermekte ve Türkçe eğitimi alanında yapılan drama çalışmalarının azlığına ilişkin düşünceyi desteklemektedir.

Araştırmanın örneklemine dâhil edilen tezlerin yıllara göre dağııımı incelendiğinde en çok tezin 2000 yılında yapıldığı görülmektedir. Bu bulgudan hareketle, alandaki ilk tezlerin yöntemin anlaşılması ve Türkçe eğitimi sürecine dâhil edilmesi konusunda çalışmalar olduğu düşünülmektedir. 2000 yılı sonrasında, tez sayısında azalma yaşanmış, 2009 yılında tez sayıları tekrar artmaya başlamıştır. Bu süreçte yapılan tezlerin tümü, yüksek lisans çalışmaları olmuştur. 2010 yılına kadar örneklem içerisinde yer alan, Türkçe eğitimi konularını içeren drama alanında doktora tezi bulunmamaktadır. Örneklem içerisinde $2010(f=2), 2011(f=1), 2014(f=1)$ yıllarında doktora tezlerinin yapıldığı tespit edilmiştir. 2014 yılından sonra ise araştırmaların sayısında bir düşüş olduğu görülmüştür.

Türkçe eğitimi konu alanı içerisinde yapılan drama tezleri betimsel çalışmalar, dil becerileri üzerinde yöntemin etkililiğini araştıran çalışmalar, yöntemin öğrenci başarısına etkisini ölçen çalışmalar, yöntemin uygulama yeterliğine ilişkin çalışmalar ve özelleştirilmiş konulara yönelik çalışmalar olmak üzere beş başlık altında incelenmiştir.

Betimsel çalışmalara bakıldığında 4 yüksek lisans tezi ile karşılaşılmış ve tezlerin üçünün 2000, birinin 2005 yılında tamamlandığı görülmüştür. Bu bulgudan hareketle, alandaki ilk tezlerin betimsel olduğu görülmektedir. Can Yaşar ve Aral'ın (2011) okul öncesi dönemde drama alanında yapılan araştırmaları inceledikleri çalışmalarında da drama alanında yapılan ilk çalışmaların, yöntemin okul öncesi eğitimde kullanımı ve çocuk eğitimindeki rolü üzerinde duran derleme çalışmaları olduğu tespit edilmiştir. Türkçe eğitiminde yapılan ilk drama çalışmalarında da Kara (2000), Türkçe öğretimi ile yaratıcı dramanın ilişkisini ortaya koymuş; Tümtürk Yılmaz (2000) dil, yaratıcı drama ve eğitimde 
drama kavramlarını açıklamıştır. Akar (2000), drama çalışmalarının öncülerinden kabul edilen Dorothy Heathcote'un "Uzman Rolü" yaklaşımına yönelik çalışmaları incelemiş, dramanın farklı bir tekniğini ele almış ve işlevsel drama ders planları sunmuştur. Serin (2005) ise ortaöğretim düzeyini hedef kitle olarak aldığı çalışmasında yaratıcı yazma çalışmalarına yönelik bir model önerisinde bulunmuştur. Bu model önerisinde rol oynama, doğaçlama, donuk imge, rol kartları, fotoğraf karesi teknikleri kullanılmıştır.

Türkçe eğitimi konularına yönelik araştırmalar, dil becerilerinin üzerinde yöntemin etkililiğini ölçme durumuna göre sınıflandırılmıştır. Sınıflandırmaya 13 tez dâhil edilmiş; tezlerin 4'ünün yazma becerisi, 2'sinin dinleme becerisi, 2'sinin okuduğunu anlama ve anladığını yazıyla anlatma becerilerini, 1'inin okuma becerisi, 1'inin konuşma becerisini, 1'inin dinleme ve konuşma becerilerini ele aldığı görülmüştür. 2 tezin ise tüm dil becerilerine yönelik olduğu tespit edilmiştir. Dil becerilerinden en çok yazma becerisi ile dramanın birleştirildiği görülmüştür. Elbir ve Yıldız (2012), yazma eğitimi üzerine yapılan lisansüstü çalışmaları değerlendirmişler ve inceledikleri çalışmaların, yaratıcı drama ile yapılan Türkçe derslerinin yazılı anlatım becerilerini, geleneksel yönteme göre daha fazla geliştirdiği sonucuna ulaştığını belirtmişlerdir. Bu bulgulardan hareketle, yazma becerisi ile yaratıcı drama yönteminin sıkıkla bir arada kullanıldığını söylemek mümkündür. Ancak Türkçe eğitimi alanında konuşma becerisi ve dramanın çok az birleştirildiği görülmüştür. Bu bulgu Alver ve Taştemir'in (2017) bulguları ile örtüşmemektedir. 2005-2016 yılları arasında konuşma becerisi üzerine yapılan lisansüstü tezleri inceleyen Alver ve Taştemir (2017), konuşma becerisinin öğretimi ve geliştirilmesinde en çok tercih edilen yöntemin yaratıcı drama yöntemi olduğunu ifade etmişlerdir.

Türkçe eğitimi konularını temel alan drama tezlerinin, genellikle deney ve kontrol gruplu bir desende gerçekleştiği, bu gruplarda yaratıcı drama yöntemi ile mevcut öğretim programına yönelik uygulamaların karşılaştırıldığı görülmüştür. Yaratıcı drama, geleneksel yönteme göre her zaman anlamlı farklılığa ulaştıran unsur olmuş; yaratıcı drama ile farklı yöntem/tekniklerin karşılaştırımasına az sayıda çalışmada yer verilmiştir. Bu çalışmalardan Koç (2009), okuma ve yazılı anlatımda yaratıcı drama yöntemi ile dramatizasyonun etkisini karşılaştırmış; Peker (2015), yazılı anlatım becerilerinin geliştirilmesinde yaratıcı drama yöntemi ile yaratıcı yazma çalışmalarının etkisini araştırmıştır. Erden (2016) ise okuduğunu anlama becerisinin gelişiminde iş birlikli yöntem, drama yöntemi ve mevcut programda önerilen okuma sürecinin etkisini karşılaştırmıştır. Belirtilen araştırmalar sonucunda Koç (2009), yaratıcı drama ile öğrenim gören grubun dramatizasyonla öğrenim gören gruptan daha fazla gelişim gösterdiği; Peker (2015), yaratıcı drama ile öğrenim gören grubun kahramanla özdeşim kurma ve akıcı bir öykü geliştirme açılarından farklılaştığı sonucuna ulaşmışlardır. Erden (2016) ise iş birlikli öğrenme yönteminin drama ve mevcut öğretim programından; dramanın ise mevcut öğretim programından daha etkili olduğu sonucuna ulaşmıştır. 
Çalışmanın örneklemi içerisinde yer alan tezler incelenirken bazı tezlerin drama planlarına yer vermediği, bu sebeple drama yöntemini hangi açıdan ele aldıkları ve hangi tekniklerle çalışmayı yönlendirdikleri belirlenememiştir. Drama uygulamalarından örneklere yer verilen tezlerde, rol oynama ve doğaçlamanın temel teknikler olarak ele alındığı; bir tezde dramatizasyonun drama ile aynı anlamda kullanıldığı; bazı çalışmalarda ise dramanın farklı birçok tekniğine yer verildiği görülmüştür.

Türkçe eğitimi konularına temel alan drama çalışmalarına bakıldığında, çalışmaların dramanın yöntem boyutunda yoğunlaştığı görülmektedir. Bu durumun, dünyada dramanın bir yöntem olarak kabul edilmesi ve yurtdışı kaynaklı araştırmalarda dramaya yöntem olarak yer verilmesinin etkisi ile gerçekleştiği düşünülmektedir. Oysa drama, bir yöntemden daha fazlasıdır. Yaratıcı drama, belirli konuların öğretilmesinde bir yöntem olarak kullanılabildiği gibi öğrenenin kişilik gelişimi ve estetik eğitimi için de öğretim programlarında kendisine yer bulmaktadır. Yaratıcı dramanın hem araç hem de amaç olarak kullanımı, sanat eğitimi olarak adlandırımaktadır (Adıgüzel, 2013, s. 103). Türkçe konularını temel alan drama çalışmalarında, dramanın sanat eğimi boyutuna değinilmediği görülmektedir.

Dil becerileri üzerinde yoğunlaşan drama tezlerinin $11^{\prime}$ inin kontrol gruplu deneysel desenlerle, 1'inin nitel araştırma deseni, 1'inin ise karma yöntemle oluşturulduğu görülmüştür. Türkçe eğitimi alanında yapılan çalışmaların eğilimleri değerlendirildiğinde, Türkçe eğitiminde betimsel çalışmalardan sonra en fazla deneysel çalışmalara yer verildiği belirtilmektedir (Yağmur Şahin, Kana ve Varışoğlu, 2013, s. 371). Türkçe eğitimi konularını temel alan drama çalışmalarının da Türkçe eğitimi çalışmalarına benzer eğilimler gösterdikleri görülmektedir.

Ece ve Çeşit (2011) drama çalışmalarının, müzik eğitimi sırasında uygulanan drama eğitiminin öğrenciler ve öğrenme üzerindeki etkilerini gözlemek amacıyla yapıldığını belirtmişlerdir. Benzer şekilde Türkçe eğitimi konularına yönelik drama tezlerinde de öğrenci başarısındaki değişim gözlenmiştir. Bu tezlerde genellikle drama yönteminin öğrenci başarısı üzerinde anlamlı bir etkisi olduğu belirlenmiştir. Ancak Selmanoğlu (2009), yaratıcı drama yönteminin kullanıldığı deney grubu ile geleneksel yönteminin kullanıldığı kontrol grubu öğrencilerinin başarılarını karşılaştırdığı çalışmasında, grupların son test başarı puanları yükselirken iki grup arasında anlamlı bir farklılık oluşmadığı sonucuna ulaşmıştır. Drama yönteminin öğrencilerin akademik başarısına olan etkisinin anlamlı bir şekilde ortaya çıkmama sebebinin, başka araştırmalara konu olabileceği düşünülmektedir. Yöntemin uygulanmasından öğrencilerin hazırbulunuşluğuna, uygulama süresinden uygulama mekânına kadar birçok unsurun, drama yönteminin kullanımına etkisi olmaktadır. 
Drama alanında yapılan tezleri inceleyen çalışmalarda, öğretmenlerin drama konusundaki görüşlerinin tespit edildiği ifade edilmektedir (Can Yaşar ve Aral, 2011). Bu çalışma örnekleminde yer alan 2 tez, yönteme yönelik Türkçe öğretmenlerinin ve öğretmen adaylarının yeterliliklerini irdelemiştir. Yöntemin uygulayıcısı olan Türkçe öğretmenlerinin yöntemi kullanma durumlarının belirlenmesi, böylelikle yöntemin uygulanmasında ortaya çıkan sorunlara çözüm aranması gerekmektedir. Ancak Türkçe eğitiminde yapılan çalışmaların eğilimlerini inceleyen Yağmur Şahin, Kana ve Varışoğlu (2013), alanda öğretmen eğitimi ile ilgili tezlerin azlığına dikkat çekmişlerdir.

Örneklemde yer alan 6 tezin, sınırlandırılmış konular üzerinde drama yönteminin etkililiğini araştırdıkları görülmüştür. Deyim ve atasözleri, öykü türü, Dede Korkut Hikâyelerine yönelik yapılan drama çalışmalarının, belirtilen konuların canlandırılmaya uygun olması sebebiyle farklı bir bakış açısı sunduğu düşünülmektedir. Bu sınıflandırmada yer alan tezlerden bir tanesinde, dil bilgisi konularının öğretiminde drama yönteminin kullanılması, Türkçe dersinin bütüncül yapısından dolayı dersin tüm aşamalarında yönteminin kullanılabilir olduğunu göstermektedir.

Incelenen drama tezlerinde, dramanın yöntem olarak ele alındığı görülmüş ve çoğunlukla geleneksel yöntem ile karşılaştırılmasına yer verilmiştir. Dil öğretiminin tek bir boyutu olmadığı düşünüldüğünde, drama çalışmalarının sanat eğitimi boyutuna Türkçe dersi kapsamında yer verilebileceği düşünülmektedir. Öğrencileri merkeze alan bu yöntemin geleneksel yöntemden daha etkili olduğu birçok araştırma ile tespit edilmiştir. Bu nedenle dramanın farklı yöntem/tekniklerle karşılaştırılmasına yönelik çalışmalar önemli olacaktır.

Türkçe dersi içerisinde dramanın bir yöntem olarak kullanılması ve drama dersinin seçmeli ders olarak açılması durumunda, bu eğitimi verecek olan öğretmenlerin, konuyla ilgili uygulama yeterliliğine sahip olma durumları belirlenmelidir. Türkçe öğretmeni adaylarının, lisans eğitimleri içerisinde aldıkları Tiyatro ve Drama Uygulamaları dersi ile dramayı bir yöntem olarak kullanmaya hazır hâle gelip gelmedikleri araştırılmalıdır.

Drama yöntemini temel alan tezlerde, uygulama sürecine ayrıntılı olarak yer verilmelidir. Böylece drama yöntemi ile yürütülen sürecin Türkçe öğretmenleri tarafından uygulanabilmesine katkı sağlanacaktır. Incelenen drama çalışmaları, farklı sürelerde gerçekleştirilmiştir. Uygulama süresi uzun planlanan, öğrencilerin gelişim düzeyine göre yöntemin birçok tekniğine yer verilen, dersin temel amaçları dışında öğrencilerin estetik gelişimine de destek sağlayan, öğrencilerin iş birlikli çalışma becerilerini geliştiren Türkçe eğitimi konularına yönelik drama yöntemini temel alan çalışmaların, alanyazına katkı sağlayacağı düşünülmektedir. Bu nedenle, doktora düzeyinde çalışmalar önem arz etmektedir. Doktora düzeyindeki araştırmacıların Türkçe eğitimi ve drama yöntemi çalışmalarına yönlendirilmesi önerilmektedir. 
Drama yönteminin öğretim sürecinde kullanılabilirliğine katkı sağlamak amacıyla, Türkçe dersi içerisindeki farklı konulara ve tüm dil becerilerine yönelik çalışmalar planlanmalıdır.

\section{Kaynaklar}

Adıgüzel, Ö. (2013). Eğitimde yaratııı drama. Ankara: Pegem Akademi.

Akar, R. (2000). Temel eğitimin ikinci aşamasında drama yöntemi ile Türkçe öğretimi: Dorothy Heatcote'un uzman rolü yaklaşımı. Yüksek Lisans Tezi, Çukurova Üniversitesi, Sosyal Bilimler Enstitüsü, Adana.

Aksoy Tokgöz, i. (2004). Ilköğretim 4. ve 5. sınıf Türkçe programlarında edebî türlerden öykünün öğretiminde yaratıcı drama yönteminin etkililiği. Yüksek Lisans Tezi, Çanakkale Onsekiz Mart Üniversitesi, Sosyal Bilimler Enstitüsü, Çanakkale.

Altıntaş, H. (2010). illköğretim 4. sınıf Türkçe ders kitaplarındaki metinlerin işlenişine yönelik hazırlanan drama yönelimi eğitim programının istenen davranışları kazandırmaya etkisi, Yüksek Lisans Tezi, Sakarya Üniversitesi Sosyal Bilimler Enstitüsü, Sakarya.

Alver, M. ve Taştemir, L. (2017). Konuşma becerisi üzerine yapılan lisansüstü tezlerin incelenmesi. International Journal of Languages' Education and Teaching, 5(3), 451-462.

Aslan, G. (2014). Öğretmen adaylarının yaratıcı drama yöntemini kullanmaya yönelik öz yeterlik algılarının incelenmesi. Yüksek Lisans Tezi, Niğde Üniversitesi, Eğitim Bilimleri Enstitüsü, Niğde.

Aytaş, G. (2003). Okullarda drama ve tiyatro eğitimi. Bilim ve Aklın Aydınlığında Eğitim, 37.

Can Yaşar, M. ve Aral, N. (2011). Türkiye'de okul öncesinde drama alanında yapılan lisansüstü tezlerin incelenmesi. Mehmet Akif Ersoy Üniversitesi Eğitim Fakültesi Dergisi, (22), 70-90.

Ece, A. S. ve Çeşit, C. (2011). Türkiye'de lisansüstü düzeyde yapılan disiplinler arası müzik araştırmaları ve sonuçları. Uluslararası Sosyal Araştırmalar Dergisi, 4 (17), 599-617.

Elbir, B. ve Yıldız, H. (2012). İlköğretim yazma eğitimi üzerine yapılan lisansüstü çalışmaların değerlendirilmesi. Akademik Bakış Dergisi, (30), 1-11.

Erden, G. (2016). Drama ve işbirlikli öğrenme yöntemlerinin 5. sınıf öğrencilerinin okuduğunu anlama becerilerine, tutuma ve kalıclığa etkileri. Yüksek Lisans Tezi, Abant İzzet Baysal Üniversitesi, Eğitim Bilimleri Enstitüsü, Bolu.

Güney, S. (2009). Drama tekniklerinin ilköğretim 4. ve 5. sınıflarda kullanımı (Dede Korkut Hikâyeleri örneği). Yüksek Lisans Tezi, Atatürk Üniversitesi, Sosyal Bilimler Enstitüsü, Erzurum.

Kara, Ö. T. (2000). Türkşe öğretiminde yaratıcı drama. Yüksek Lisans Tezi, Atatürk Üniversitesi, Sosyal Bilimler Enstitüsü, Erzurum.

Kara, Ö. T. (2010). Dramayla öykü oluşturma yönteminin ilköğretim ikinci kademe Türkçe öğretimine etkisi. Doktora Tezi, Selçuk Üniversitesi, Eğitim Bilimleri Enstitüsü, Konya.

Karacil, M. (2009). Illköğretim 1. kademede yaratıcı drama yönteminin öğrencinin akademik başarısına etkisi. Yüksek Lisans Tezi, Kafkas Üniversitesi, Sosyal Bilimler Enstitüsü, Kars.

Karakuş, F. (2000). Drama yönteminin ilköğretim beşinci sınıf öğrencilerinin öykü yazma becerilerine etkisi. Yüksek Lisans Tezi, Çukurova Üniversitesi, Sosyal Bilimler Enstitüsü, Adana.

Karasar, N. (2012). Bilimsel araştırma yöntemi. Ankara: Nobel Yayınları.

Karateke, E. (2006). Yaratıcı dramanın ilköğretim II. kademede 6.sınıf öğrencilerinin yazıı anlatım becerilerine olan etkisi. Yüksek Lisans Tezi, Mustafa Kemal Üniversitesi, Sosyal Bilimler Enstitüsü, Hatay.

Kaya Güler, i. (2008). Illköğretim dördüncü sınıf Türkçe dersinde yaratıcı drama yönteminin etkililiği. Yüksek Lisans Tezi, Ondokuz Mayıs Üniversitesi, Sosyal Bilimler Enstitüsü, Samsun.

Kazıcı, E. (2008). ilköğretim ikinci kademe Türkçe derslerinde deyim ve atasözlerinin öğretiminde dramatizasyon yönteminin etkililik düzeyi. Yüksek Lisans, Selçuk Üniversitesi, Sosyal Bilimler Enstitüsü, Konya.

Koç, K. (2009). illköğretim 7. sınıf Türkçe dersinde dramatizasyonla yaratııı dramanın karşılaştırılması. Yüksek Lisans Tezi, Ondokuz Mayıs Üniversitesi, Sosyal Bilimler Enstitüsü, Samsun. 
Köklü, S. (2003). Türkçe öğretiminde 7. ve 8. sınıf öğrencilerine dinlediğini anlama davranışının kazandırılmasına dramatizasyonun etkisi. Yüksek Lisans Tezi, Marmara Üniversitesi, Eğitim Bilimleri Enstitüsü, İstanbul.

Maden, S. (2010). Illköğretim 6. sınıf Türkçe dersinde drama yönteminin temel dil becerilerinin kazanımına etkisi (sevgi teması örneği). Doktora Tezi, Atatürk Üniversitesi, Sosyal Bilimler Enstitüsü, Erzurum.

Nurses, G. (2014). 7. sınıf Türkçe dersinde drama yöntemini kullanmanın öğrenci başarısına etkileri. Yüksek Lisans Tezi, Atatürk Üniversitesi, Eğitim Bilimleri Enstitüsü, Erzurum.

Özcan, Ş. (2013). Yaratıcı dramanın anlayarak anlatma becerilerinin geliştirilmesine etkisi. Yüksek Lisans Tezi, Gazi Üniversitesi, Eğitim Bilimleri Enstitüsü, Ankara.

Pat, Ö. (2017). Ilkokul 3. sınıf Türkçe dersinde yaratıcı drama yönteminin konuşma becerilerini geliştirmeye etkisi. Yüksek Lisans Tezi, Bartın Üniversitesi, Eğitim Bilimleri Enstitüsü, Bartın.

Peker, Ş. (2015). Yazılı anlatım becerilerinin geliştirilmesinde yaratıcı drama tekniklerinden özel mülkiyet tekniğinin yaratıcı yazma yaklaşımı ile karşılaştırılması. Yüksek Lisans Tezi, Ankara Üniversitesi, Eğitim Bilimleri Enstitüsü, Ankara.

Selmanoğlu, E. (2009). Illköğretim 5. sınıf Türkçe dersinde yaratıcı dramanın öğrenci başarısına etkisi. Yüksek Lisans Tezi, Abant İzzet Baysal Üniversitesi, Sosyal Bilimler Enstitüsü, Bolu.

Serin, A. (2005). Yaratıcı dramayla kurgulanmış yaratıcı yazma çalışmalarına ilişkin bir model önerisi. Yüksek Lisans Tezi, Ankara Üniversitesi, Sosyal Bilimler Enstitüsü, Ankara.

Şenol, Z. (2011). Deyimlerin yaratıcı drama yöntemiyle öğretimi. Yüksek Lisans Tezi, Atatürk Üniversitesi, Eğitim Bilimleri Enstitüsü, Erzurum.

Tutuman, O. Y. (2011). Türkçe öğretmenlerinin yaratıcı drama uygulama yeterlilikleri. Yüksek Lisans Tezi, Dokuz Eylül Üniversitesi, Eğitim Bilimleri Enstitüsü, İzmir.

Tümtürk Yılmaz, T. (2000). Türkçe öğretiminde yaratıcı drama yönetimi ile diksiyon becerileri kazandırmaya ilişkin bir model önerisi yaklaşımı. Yüksek Lisans Tezi, Ankara Üniversitesi, Sosyal Bilimler Enstitüsü, Ankara

Türkel, A. (2011). Yaratıcı dramanın yaratıcı yazma başarısına ve yazmaya karşı tutuma etkisi: ilköğretim 8. sınıf. Doktora Tezi, Dokuz Eylül Üniversitesi, Eğitim Bilimleri Enstitüsü, İzmir.

Uysal, B. (2014). Dinleme ve konuşma becerilerinin kazandırılmasında yaratıcı drama temelli bir model önerisi. Doktora Tezi, Gazi Üniversitesi, Eğitim Bilimleri Enstitüsü, Ankara.

Ünsal, B. (2005). Illköğretim ikinci kademe (6,7, 8. sınıflar) Türkçe dersinde drama yönteminin çocukların dil ve anlatım becerilerine katkısı. Yüksek Lisans Tezi, Gazi Üniversitesi, Eğitim Bilimleri Enstitüsü, Ankara.

Ütkür, N. (2018). Hayat bilgisi derslerinde kullanılan yöntem ve etkinliklerin tespiti: lisansüstü tezlerin incelenmesi. Manisa Celal Bayar Üniversitesi Sosyal Bilimler Dergisi, 16(1), 101-122.

Yağmur Şahin, E., Kana, F. ve Varışoğlu, B. (2013). Türkçe eğitimi bölümlerinde yapılan lisansüstü tezlerin araştırma eğilimleri. International Journal of Human Sciences, 10(2), 356-378.

Yazkan, M. (2000). Ilköğretim okullarının ı. kademesinde dinlediğini anlama davranışının kazandırılmasına dramatizasyonun etkisi. Yüksek Lisans Tezi, Marmara Üniversitesi, Sosyal Bilimler Enstitüsü, İstanbul.

Yeşilyurt, E. (2011). 6. sınıflarda yapım eklerinin öğretimine yaratıcı drama yönteminin etkisi. Yüksek Lisans Tezi, Abant İzzet Baysal Üniversitesi, Sosyal Bilimler Enstitüsü, Bolu.

\section{Extended Abstract}

Introduction

Turkish language education is carried out in order to improve individuals' listening, reading, speaking, and writing skills which take place under comprehension and expressing processes. Therefore, Turkish language education aims to develop the effective and efficient use of the language.

It is observed that learning by doing and experiencing becomes very effective among the methods and techniques used for teaching Turkish language. Therefore, the drama method has become a part of this process. The method which includes different headings such as drama, creative drama, educational drama etc. helps students learn by gaining experience. Drama allows students experience events and situations that they faced or might face. This is one of objectives of the Turkish language education. 
In literature, there are some studies which focus on use of the drama method on different disciplines; however, when it comes to Turkish language education, there is observed no analysis of studies which aim at teaching Turkish Language Education via drama method. This study aims to make an analysis for master's and doctoral theses based on teaching Turkish language via drama method.

\section{Method}

In the study, screening model was used. Research population consists of 386 theses which were scanned under the topic of Education and Teaching at the National Thesis Center's Data Base and containing the word drama within its title. After filtering those studies with inclusive criteria, the study sample consists of 30 theses on Turkish language education.

Theses were tabulated depending on thesis name, year, thesis type, access type, department, university, institute. All theses included in the study sample were read in detail.

The theses at the sample were examined under five headings as descriptive studies, studies investigating the effectiveness of the method on language skills, studies on measuring the method's effect on students' success, studies on teachers' implementation sufficiency levels of drama method, and studies regarding the use of drama for teaching specific content area of Turkish language course.

\section{Conclusion and Discussion}

It is found that the $85 \%$ of the 386 theses in the research population were master's and the $15 \%$ were doctoral theses. Accordingly, the drama theses in the field of education are mostly accumulated at the master's degree level.

The drama theses on education and teaching are observed to have increased since 1999. There is seen an increase of interest in drama method because it becomes widespread all around the world and it started to take place in the curriculum in Turkey. Education theses based on drama method have been studied in 52 different departments. This finding shows that drama is used in many disciplines. However, the different headings used for the similar departments negatively affects the situation.

The most of the drama theses on Turkish language education were conducted in 2000 . The first theses in the field are descriptive theses that discuss how to use the method. Furthermore, it is seen that drama theses on Turkish language education are mostly written regarding language skills. There are 13 theses that measure the drama method's effect on reading, listening, speaking and writing skills. It is noticed that the theses addressing language skills were mostly carried out by using experimental design; and drama method mostly aimed at developing writing skill. In addition, 5 theses analyze how the use of drama method affects students' achievement in Turkish language course. It is noticed that there were 2 studies examining the proficiency of in-service and pre-service Turkish language teachers in the drama method. Correspondingly, the number of studies is considered to be insufficient in relation to the teachers' proficiency levels who are the implementers of the method. The 6 theses in the sample are seen to examine the effectiveness of the drama method on the specific topics. Thanks to these theses, it is realized that drama can be used in all areas of Turkish language course.

Based on the study results; it can be suggested to increase the number of dissertations regarding the drama method's effectiveness on Turkish language education. There is also a need for studies showing good examples of drama method. 